\title{
PENERAPAN MODEL PEMBELAJARAN KOLABORATIF UNTUK MENINGKATKAN AKTIVITAS DAN HASIL BELAJAR RENCANA ANGGARAN BIAYA SISWA KELAS XII KOMPETENSI KEAHLIAN TEKNIK GAMBAR BANGUNAN SMKN 2 SIATAS BARITA - TAPANULI UTARA
}

\author{
Pahala Arion Lasidos' ${ }^{1}$, Zulkifli Matondang ${ }^{2}$ \\ ${ }^{1}$ Alumni Program Studi Pendidikan Teknik Bangunan, Fakultas Teknik UNIMED \\ ${ }^{2}$ Dosen Pengajar Jurusan Pendidikan Teknik Bangunan, Fakultas Teknik UNIMED \\ (zulkiflimato@gmail.com)
}

\begin{abstract}
ABSTRAK
Penelitian ini bertujuan untuk meningkatkan aktivitas dan hasil belajar rencana anggaran biaya siswa. Jenis penelitian ini adalah Penelitian Tindakan Kelas (PTK) yang dilaksanakan di SMKN 2 Siatas Barita. Subjek penelitian adalah model pembelajaran kolaboratif dan objek penelitiannya adalah aktivitas dan hasil belajar siswa kompetensi keahlian TGB kelas XI SMKN 2 S iatas Barita. Teknik pengumpulan data penelitian ini adalah tes dan lembar observasi aktivitas siswa untuk melihat aktivitas belajar siswa selama proses pembelajaran berlangsung. Data hasil observasi terhadap aktivitas siswa menunjukkan adanya peningkatan aktivitas belajar siswa dari siklus I ke siklus II. Pada siklus I diperoleh 11 siswa $(55 \%)$ untuk kategori tidak aktif, 8 siswa (40\%) untuk kategori cukup aktif dan 1 siswa (5\%) untuk kategori aktif. Sedangkan pada siklus II diperoleh 8 siswa (40\%) untuk kategori cukup aktif, 10 siswa $(50 \%)$ untuk kategori aktif dan 2 siswa $(10 \%)$ untuk kategori sangat aktif. Untuk nilai rata-rata aktifitas belajar siswa pada siklus I yaitu 68 meningkat menjadi 82 pada siklus II. Data nilai hasil belajar siswa pada siklus I diperoleh 16 siswa (80\%) untuk kategori tidak kompeten dan 4 siswa (20\%) untuk kategori kompeten. Siklus II diperoleh 16 siswa (80\%) untuk kategori kompeten dan 4 siswa (20\%) untuk kategori sangat kompeten. Nilai rata-rata hasil belajar pada siklus I yaitu 70 meningkat menjadi 85 pada siklus II. Dapat disimpulkan bahwa dengan menerapkan model pembelajaran kolaboratif dapat:1) meningkatkan aktivitas belajar menyusun rencana anggaran biaya siswa kels XI kompetensi keahlian teknik gambar bangunan SMKN 2 Siatas Barita ,2) meningkatkan hasil belajar menyusun rencana anggaran biaya siswa kelas XI kompetensi keahlian teknik gambar bangunan SMKN 2 Siatas Barita .
\end{abstract}

Kata kunci: Pembelajaran Kolaboratif, Aktivitas Belajar, Hasil Belajar

\begin{abstract}
This study aims to improve the activity and the learning outcomes of students budget plan.This research is Classroom Action Research (CAR), which held at SMKN 2 Siatas Barita. The subjects were a model of collaborative learning and research object is the activity and student learning outcomes TGB competency skills class XI SMK 2 Siatas Barita. Data collection techniques in this study was a tes and observation of student activity sheet to see the learning activities of students during the learning process takes place. The data of observations of student activity showed an increase in the activity of student learning from the first cycle to the second cycle. In the first cycle obtained by 11 students (55\%) for the category of incompetent, 8 students (40\%) to the category of fairly competent and 1 student (5\%) for the competent category. While in the second cycle was obtained 8 students (40\%) to the category of fairly competent, 10 students (50\%) for the category of competent and 2 students (10\%) to the category of very competent. Average value aktivitas student learning in the first cycle is 68 increased to 82 in the second cycle. The data values student learning outcomes obtained in the first cycle of 16 students (80\%) for the category of incompetent and 4 students (20\%) for the competent category. While in the second cycle was obtained 16 students $(80 \%)$ for the category of competent and 4 students $(20 \%)$ to the category of very competent. Average value of
\end{abstract}


learning outcomes in the first cycle of 70 increased to 85 in the second cycle.It can be concluded that by applying collaborative learning model can be: 1) increase the learning activity plan budget kels XI student competence building engineering drawings SMK 2 Siatas Barita, 2) improve learning outcomes plan budget class XI student competence building engineering drawings SMKN 2 Siatas Barita.

Keywords: Collaborative Learning, Learning Activity, Learning Outcomes,

\section{Pendahuluan}

Pendidikan adalah segala pengalaman belajar yang berlangsung dalam segala lingkungan dan sepanjang hidup serta pendidikan dapat diartikan sebagai pengajaran yang diselenggarakan di sekolah sebagai lembaga pendidikan formal (Mudyahardjo, 2001).

Menurut Buchori dalam Trianto (2007:1) "pendidikan yang baik adalah pendidikan yang tidak hanya mempersiapkan siswanya untuk sesuatu profesi atau jabatan, tetapi untuk menyelesaikan masalah-masalah yang dihadapinya dalam kehidupan sehari-hari".

Menurut Daryanto (2010) faktor-faktor yang dapat mempengaruhi hasil belajar siswa dapat dibedakan menjadi 3 (tiga) macam, yaitu: (1) Faktor Internal (2) Faktor Eksternal ( (3) Faktor pendekatan belajar (approach to learning), Sehingga sebagian besar hasil belajar siswa tidak mencapai nilai batas ketuntasan belajar yang ditetapkan.

Dari pendapat diatas, faktor-faktor yang mempengaruhi hasil belajar yaitu faktor internal, eksternal, dan pendekatan pembelajaran yang dilakukan oleh guru.

Sesuai dengan Kurikulum Spektrum SMK (2008 tujuan pembelajaran di Sekolah Menengah Kejuruan adalah untuk :

1) Menyiapkan siswa untuk memasuki lapangan kerja serta mengembangkan sikap professional,

2) Menyiapkan siswa agar mampu memiliki karier, mampu berkompetensi dan mampu mengembangkan diri,

3) Menyiapkan tenaga kerja menengah untuk mengisi kebutuhan dunia usaha dan industri pada saat ini maupun pada saat yang akan datang, dan

4) Menyiapkan tamatan agar menjadi warga Negara yang produktif, adaptif dan kreatif Kompetensi Keahlian Teknik Gambar Bangunan adalah suatu kompetensi pendidikan kejuruan teknik yang melaksanakan serangkaian kegiatan belajar yang meliputi berbagai standar kompetensi keteknikan. Perhitungan Rencana
Anggaran Biaya adalah salah satu standar kompetensi yang diajarkan di SMK pada kompetensi Keahlian Teknik Gambar Bangunan untuk kelas XII.

Berdasarkan hasil observasi awal yang penulis lakukan pada hari Selasa dan Rabu tanggal 21 dan 22 Januari 2014 di SMKN 2 Siatas Barita, menunjukkan bahwa hasil belajar standar kompetensi Rencana Anggaran Biaya siswa kelas XII TGB dapat dilihat pada Tabe 11 berikut :

Tabel 1 Perolehan Nilai Hasil Belajar Rencana Anggaran Biaya Kelas XII kompetensi Keahlian Teknik Gambar Bangunan

\begin{tabular}{|l|c|c|c|}
\hline $\begin{array}{c}\text { Tahun } \\
\text { Pelajaran }\end{array}$ & Nilai & $\begin{array}{l}\text { Jumlah } \\
\text { Siswa } \\
\text { (orang) }\end{array}$ & Persentase \\
\hline $2010 / 201$ & $<70,00$ & 20 & $58,60 \%$ \\
1 & $7,00-7,90$ & 9 & $26,00 \%$ \\
& $8,00-8,90$ & 4 & $11,74 \%$ \\
& $9,00-10$ & 1 & $3,66 \%$ \\
\hline $2011 / 201$ & $<70,00$ & 10 & $33,3 \%$ \\
2 & $7,00-7,90$ & 15 & $50 \%$ \\
& $8,00-8,90$ & 5 & $16,7 \%$ \\
\hline $2012 / 201$ & $9,00-10$ & - & \\
\hline 3 & $<70,00$ & 14 & $50 \%$ \\
& $7,00-7,90$ & 9 & $32,14 \%$ \\
& $8,00-8,90$ & 5 & $17,86 \%$ \\
& $9,00-10$ & \multicolumn{2}{|c}{} \\
\hline
\end{tabular}

Sumber: DKN SMKN 2 Siatas Barita

Dengan standar kelulusan minimal untuk standar kompetensi Rencana Anggaran Biaya pada siswa Kompetensi Keahlian Teknik Gambar Bangunan SMKN 2 Siatas Barita adalah 70,00. Dari tabel di atas dapat dilihat kemampuan dan keterampilan siswa kelas XII kompetensi Keahlian Teknik Gambar Bangunan SMKN 2 Siatas Barita.

Dari hasil observasi, model pembelajaran yang digunakan guru pada umumnya belum berorientasi pada peserta didik, maka perlu 


\section{Penerapan Model Pembelajaran Kolaboratif Untuk Meningkatkan Aktivitas dan hasil Belajar Rencana Anggaran Biaya Siswa Kelas XII Kompetensi keahlian Teknik Gambar Bangunan SMKN 2 Siatas Barita - Tapanuli Utara}

dikembangkan model pembelajaran yang tepat sehingga dapat meningkatkan hasil belajar siswa.

Adapun model pembelajaran yang cocok untuk standar kompetensi Rencana Anggaran Biaya salah satunya adalah model pembelajaran kolaboratif. Penulis ingin melakukan penelitian untuk menerapkan model pembelajaran yang mendorong siswa aktif dan saling berinteraksi sesama siswa juga antara siswa dan guru dalam menguasai materi pelajaran untuk mencapai prestasi yang maksimal, sehingga sebagian besar hasil belajar siswa mencapai nilai batas ketuntasan belajar yang ditetapkan. Penelitian ini melalui pendekatan tindakan kelas.

Memperhatikan pentingnya model pembelajaran yang digunakan dalam meningkatkan hasil belajar Perhitungan Rencana Anggaran Biaya maka penulis tertarik untuk melakukan penelitian dengan menerapan Model Pembelajaran Kolaboratif Untuk Meningkatkan Aktivitas Dan Hasil Belajar Rencana Anggaran Biaya Siswa Kelas XII SMKN 2 Siatas Barita Tapanuli Utara.

Menurut John Myers (1991) kata kolaborasi berasal dari bahasa Latin dengan memfokuskan pada proses, Sementara itu, menurut Ted Panitz (1996), istilah kolaborasi menunjuk pada filsafat interaksi dan gaya hidup personal.

Pembelajaran kolaboratif dapat menyediakan peluang untuk menuju pada kesuksesan praktekpraktek pembelajaran. Sebagai teknologi untuk pembelajaran, pembelajaran kolaborasi melibatkan partisipasi aktif para siswa dan meminimisasi perbedaan-perbedaan antar individu dan juga telah menambah momentum pendidikan formal dan informal dari dua kekuatan yang bertemu, yaitu:

1) Realisasi praktek,

2) Menumbuhkan kesadaran berinteraksi sosial dalam upaya mewujudkan pembelajaran bermakna.

Ide pembelajaran kolaborasi bermula dari perpsektif filosofis terhadap konsep belajar. Untuk dapat belajar, seseorang harus memiliki pasangan. Pada tahun 1916, John Dewey, menulis sebuah buku "Democracy and Education" yang isinya bahwa kelas merupakan cermin masyarakat dan berfungsi sebagai laboratorium untuk belajar tentang kehidupan nyata.
Pemikiran Dewey yang utama tentang pendidikan (Jacob et al., 1996), adalah:

a. Siswa hendaknya aktif, learning by doing

b. Belajar hendaknya didasari motivasi intrinsik

c. Pengetahuan adalah berkembang, tidak bersifat tetap

d. Kegiatan belajar hendaknya sesuai dengan kebutuhan dan minat siswa

e. Pendidikan harus mencakup kegiatan belajar dengan prinsip saling memahami dan saling menghormati satu sama lain, artinya prosedur demokratis sangat penting.

f. Kegiatan belajar hendaknya berhubungan dengan dunia nyata dan bertujuan mengembangkan dunia tersebut.

Pembelajaran kolaboratif"merupakan salah satu model pembelajaran di antara berbagai model. Model pembelajaran kolaboratif sering kali digunakan dalam proses pembelajaran.

Dengan demikian, sebelum menentukan model pembelajaran, perlu dirumuskan tujuan pembelajaran yang jelas yang dapat diukur keberhasilannya, agar dalam penyusunan langkah-langkah pembelajaran, pemanfaatan berbagai fasilitas dan sumber pembelajaran semuanya dapat diarahkan dalam upaya pencapaian tujuan tersebut. Maka dapat disimpulkan bahwa model pembelajaran digunakan untuk memperoleh kesuksesan atau keberhasilan dalam mencapai tujuan pembelajaran.

Menurut Johnsons (1974), sekurangkurangnya terdapat lima unsur dasar agar dalam suatu kelompok terjadi pembelajaran kolaboratif, yaitu:
a. Saling ketergantungan positif
b. Pertanggungjawaban individu
c. Keterampilan berkolaborasi
d. Keefektifan proses kelompok

\section{Metodologi Penelitian}

Penelitian tindakan kelas ini dilaksanakan di SMKN 2 Siatas Barita, Kompetensi keahlian teknik gambar bangunan pada mata pelajaran rencana anggaran biaya. Penelitian ini dilaksanakan pada kelas XII bulan Agustus 2014.

Adapun yang menjadi subyek penelitian ini adalah pembelajaran kolaboratif dan yang menjadi obyek adalah aktivitas dan hasil belajar 
TGB kelas XII SMKN 2 Siatas Barita. Berikut ini langkah-langkah pembelajaran kolaboratif:

a. Para siswa dalam kelompok menetapkan tujuan belajar dan membagi tugas sendirisendiri.

b. Semua siswa dalam kelompok membaca, berdiskusi, dan menulis..

c. Kelompok kolaboratif bekerja secara bersinergi mengidentifikasi, mendemontrasikan, meneliti, menganalisis, dan memformulasikan jawaban-jawaban tugas atau masalah dalam Materi atau masalah yang ditemukan sendiri.

d. Setelah kelompok kolaboratif menyepakati hasil pemecahan masalah, masing-masing siswa menulis laporan sendiri-sendiri secara lengkap.

e. Guru menunjuk salah satu kelompok secara acak (selanjutnya diupayakan agar semua kelompok dapat giliran ke depan) untuk melakukan presentasi hasil diskusi kelompok kolaboratifnya di depan kelas, siswa pada kelompok lain mengamati, mencermati, membandingkan hasil presentasi tersebut, dan menanggapi. Kegiatan ini dilakukan selama lebih kurang 20-30 menit.

f. Masing-masing siswa dalam kelompok kolaboratif melakukan elaborasi, inferensi, dan revisi (bila diperlukan) terhadap laporan yang akan dikumpulan.

$>$ Laporan masing-masing siswa terhadap tugas-tugas yang telah dikumpulkan, disusun perkelompok kolaboratif.

> Laporan siswa dikoreksi, dikomentari, dinilai, dikembalikan pada pertemuan berikutnya, dan didiskusikan.

Prosedur penelitan merupakan tahapantahapan yang dilakukan dalam proses penelitian. Prosedur yang akan dilakukan adalah sebagai berikut:

\section{1) Siklus I}

a. Perencanaan.

Maka perencanaan yang akan dilakukan di siklus I adalah sebagai berikut :

(a) Merencanakan pembelajaran dengan Penerapan model kolaboratif.

(b) Menyiapkan sumber belajar

(c) Mempersiapkan format observasi untuk melihat tingkat hasil belajar siswa.

\section{b. Pelaksanaan tindakan}

Pelaksanaan tindakan yang akan dilakukan adalah

(a) Menyampaikan tujuan pembelajaran dan memberi informasi kepada siswa

(b) Memberi yang telah disusun sebelum nya dengan menerapkan model kolaboratif.

(c) Melaksanakan skenario yaitu penerapan model kolaboratif.

\section{c. Pengamatan}

Dalam pengamatan penelitian mengamati aktivitas siswa, yang ditulis pada lembar aktivitas yang telah disusun sebelum pengajaran dimulai, adapun aktivitas tersebut meliputi :
(a) Memberikan pertanyaan.
(b) Memberikan saran.
(c) Membuat kesimpulan dan,
(d) Memberikan jawaban.

\section{d. Refleksi}

Refleksi dilakukan dengan menganalisis hasil kerja peserta didik, lembar pengamatan yang telah diisi dari hasil diskusi yang dilakukan peneliti dan pengamat. Adapun Refleksi :

(a) Mengkaji berbagai hal yang terjadi dan seharusnya dilakukan agar tidak terjadi kesalahan.

(b) Membuat kesimpulan sebagai dasar untuk melaksanakan siklusberikutnya

\section{2) Siklus II}

Pada prinsipnya semua kegiatan siklus II mirip dengan siklus I. Siklus II merupakan perbaikan pada siklus I, terutama didasarkan atas hasil refleksi pada siklus I. Secara garis besarnya adalah sebagai berikut.

\section{a. Perencanaan}

Meninjau kembali rancangan pembelajaran yang disiapkan untuk siklus 2 dengan melakukan revisi sesuai hasil refleksi 1.

Adapun perencanaan nya
(a) Mengidentifikasi masalah yang muncul pada siklus I dan penetapan alternatif pemecahan masalah
(b) Merencanakan pengembangan kompetensi yang dilakasanakan pada 


\section{Penerapan Model Pembelajaran Kolaboratif Untuk Meningkatkan Aktivitas dan hasil Belajar Rencana Anggaran Biaya Siswa Kelas XII Kompetensi keahlian Teknik Gambar Bangunan SMKN 2 Siatas Barita - Tapanuli Utara}

siklus II, untuk menyelesaikan permasalahan pada siklus I

\section{b. Pelaksanaan tindakan}

Pelaksanaan tindakan yang akan dilakukan adalah sama seperti pelaksanaan pada siklus I.

\section{c. Pengamatan}

Guru dan peneliti melakukan pengamatan yang sama seperti pada siklus I.

\section{d. Refleksi}

Refleksi pada siklus II ini dilakukan untuk melakukan penyempurnaan pembelajaran dengan menggunakan model kolaboratif di harapkan dapat meningkatkan Aktivitas dan hasil belajar peserta didik.

Teknik pengumpulan data dalam penelitian ini menggunakan tes dan Observasi Aktvitas

1) Observasi Aktivitas siswa

Obsevasi digunakan untuk mengumpulkan data tentang aktivitas belajar siswa dalam proses belajar mengajar dan penerapan model pembelajaran kolaboratif. Observasi yang dilakukan dalam penelitian ini dengan mengunakan lembar Observasi aktivitas siswa.

a. Aspek Aktivitas yang dinilai

(a) Memberikan pertanyaan.

(b) Memberikan saran

(c) Membuat kesimpulan dan,

(d) Memberikan jawaban

b. Kriteria skor

$1=$ Tidak pernah melakukan

$2=$ Dilakukan namun jarang

$3=$ Sering dilakukan

$4=$ Sangat sering dilakukan

c. Kriteria Penilaian

$$
\begin{array}{ll}
12-16 & \text { : Sangat Aktif } \\
8-12 & \text { : Aktif } \\
4-8 & \text { : Cukup Aktif } \\
0-4 & \text { : Kurang Aktif }
\end{array}
$$

Skor berdasarkan kriteria penilaian, maka 16 adalah skor tertinggi yang diperoleh dari kriteria penilian (4), dan aspek yang dinilai ada sebanyak 4 aspek, sehingga $4 \times 4=16$.

Dari hasil lembar aktivitas belajar siswa yang diperoleh kemudian dilakukan penganalisisan untuk menghitung persentase tingkat aktivitas siswa selama proses belajar mengajar berlangsung, yaitu dengan rumus:
Nilai Aktivitas siswa $=\frac{\text { Jumlahsiswayangaktif }}{\text { Jumlahseluruhsiswa }}$ XI 100 (Aqib, dkk. 2010)

Untuk mengetahui peningkatan aktivitas belajar siswa, jika dikelas telah terdapat $>70$ siswa yang mencapai kategori aktif dengan skor perolehan 12, maka ketuntasan secara keseluruhan telah mencapai.

\section{2) Tes Hasil Belajar}

Tes yang digunakan dalam penelitian disesuaikan dengan tujuan yang hendak dicapai. Adapun tes yang diberikan berbentuk Pilihan berganda sebanyak 40 soal dengan empat pilihan,dan dibagi dua, dimana 20 soal untuk siklus pertama dan 20 untuk siklus kedua. Dan setelah dilaksanakan Uji Intrumen Tes untuk melihat hasil Validitastes, Sehingga didapat pada Siklus pertama 3 (tiga) soal yang tidak Valid dan Siklus kedua terdapat 3 (soal) yang tidak Valid. maka setelah pelaksanaan tindakan pada kompetensi yang telah ditetapkan Secara lebih detail distribusi instrumen tes

Persentase Nilai $=\frac{\text { Nilaiyangdiperole hsiswa }}{\text { jumla hnilai }}$ XI 100

Kategori penilaian:

$<70 \quad=$ Tidak Kompoten

$70-79$ = Cukup Kompoten

$80-89=$ Kompoten

$90-100=$ Sangat Kompoten

Hasil belajar siswa di analisis dengan melihat ketuntasan belajar siswa.Berdasarkan Kriteria ketuntasan minimal siswa (KKM) yang ditetapkan dalam kompetensi dasar pada penelitian tindakan kelas ini, maka siswa dikatakan kopotensi jika siswa memperoleh skor $\geq 70$. Dan suatu kelas dikatakan tuntas terhadapa sustu materi pelajaran jika skor rata - rata kelas mencapai 70. Nilai rata - rata kelas dapat dihitung:

Nilai rata-rata kelas $($ mean $)=\frac{\sum x_{i}}{N}$,

Dengan :

$\Sigma \mathrm{XI}_{\mathrm{i}}=$ jumlah nilai siswa,

$\mathrm{N}=$ jumlah siswa.

Dari uraian diatas dapat diketahui ketuntasan secara keseluruhan (klasikal) dengan rumus sebagai berikut:

$$
P=\frac{\sum \text { SiswayangTuntasBelajar }}{\sum \text { Siswa }} \times 100 \%
$$




\section{Pahala Arion Lasidos - Zulkifli Matondang}

(Aqib, dkk 2010)

Keterangan:

$\mathrm{P}=$ Persentase ketuntasan belajar klasikal

Data hasil belajar siswa dianalisis

dengan Kriteria Ketuntasan Minimal (KKM)

yang ditetapkan oleh sekolah. Untuk menggunakan gambaran tentang hasil belajar siswa dinyatakan tuntas belajar jika siswa memperoleh skor 70 dan dinyatakan mencapai ketuntasan jika skor rata-rata kelas 70 atau 70\% menurut Kriteria Ketuntasan Minimal (KKM) yang ditetapkan oleh sekolah.

Berdasarkan kriteria ketuntasan belajar, jika kelas tersebut telah terdapat $70 \%$ siswa yang telah mencapai persentase Nilai $\geq 70$ maka ketuntasan secara keseluruhan telah tercapai. (Berdasarkan kriteria sekolah).

\section{Hasil Penelitian dan Pembahasan}

\subsection{Paparan Hasil Observasi Aktivitas Belajar Siswa Siklus I}

Ini terdapat 16 Siswa dikatakan Kurang Aktif, 4 Siswa dikatakan Aktif, Hal ini berarti bahwa Aktivitas belajar siswa belum sesuai dengan yang diharapkan, sehingga guru akan melanjutkan pembelajaran. Grafik yang menunjukkan tingkat Aktivitas belajar siswa selama proses belajar mengajar siklus I berlangsung dapat dilihat pada gambar dibawah ini :

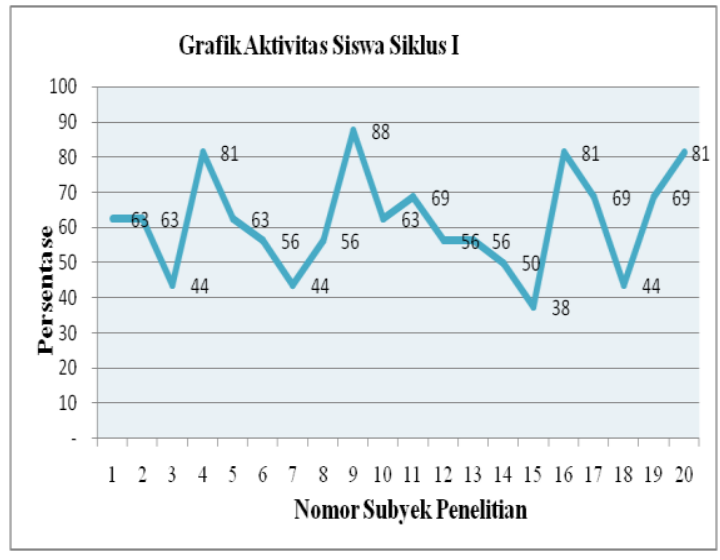

Gambar 1 Grafik Aktivitas Belajar Siklus I

\subsection{Paparan Hasil Belajar Siswa Siklus I}

Hasil belajar siswa diperoleh dari tes hasil belajar yang dikerjakan oleh siswa sesudah proses belajar mengajar dilaksanakan.

Dari hasil tes belajar siswa dengan kategori tidak kompeten sebanyak 17 orang, kompeten 3 orang cukup kompeten 1 orang. Dari nilai ideal 100, didapat nilai perolehan tidak tuntas dapat disebabkan oleh Pembagian kelompok yang tidak merata berdampak pada hasil belajar siswa yang belum memuaskan. Sehingga perlu dilanjut ke siklus II untuk meningkatkan aktivitas dan hasil belajar siswa dengan memperhatikan kelemahan yang terjadi selama pelaksanaan proses pembelajaran siklus I.

Grafik yang menunjukkan hasil belajar siswa selama proses belajar mengajar siklus I berlangsung dapat dilihat pada gambar dibawah ini:

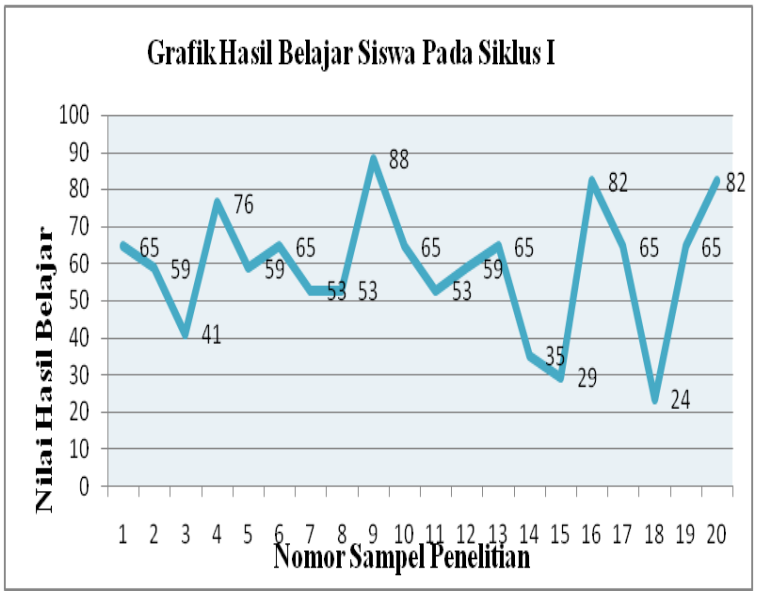

Gambar 2 Grafik Hasil Belajar Siklus I

\subsection{Paparan Hasil Aktivitas Belajar Siswa Siklus II}

Hasil Observasi Aktivitas Siswa diperoleh dari kegiataan siswa dalam proses pembelajaran ini terdapat 5 Siswa dikatakan kurang Aktif, 11 siswa dikatakan Aktif, 4 Siswa dikatakan Sangat Aktif. Maka dapat disimpulkan Aktivitas pada Siklus II telah mengalami perbaikan dan peningkatan dari Siklus I. Grafik yang menunjukkan tingkat Aktivitas belajar siswa selama proses belajar mengajar siklus II berlangsung dapat dilihat pada gambar dibawah ini : 


\section{Penerapan Model Pembelajaran Kolaboratif Untuk Meningkatkan Aktivitas dan hasil Belajar Rencana Anggaran Biaya Siswa Kelas XII Kompetensi keahlian Teknik Gambar Bangunan SMKN 2 Siatas Barita - Tapanuli Utara}

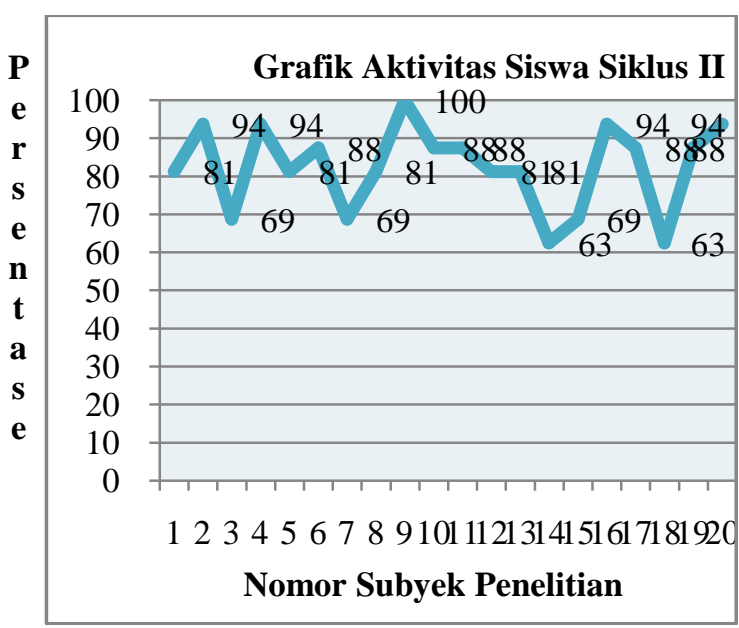

Gambar 3 Grafik Aktivitas Belajar Siklus II

\subsection{Paparan Hasil Belajar Siswa Siklus II}

Hasil belajar siswa diperoleh dari tes hasil belajar yang dikerjakan oleh siswa sesudah proses pembelajaran dilaksanakan.

Dari hasil tes belajar pada siklus II pada kategori Tidak Kompeten 5 0rang, kompeten 11 orang, dan sangat kompeten 4 orang. Dari nilai perolehan rata-rata dapat digolongkan dalam kategori kompeten. Sesuai dengan data tersebut maka penerapan model pembelajaran tipe kolaboratif dapat meningkatkan aktivitas dan hasil belajar rencana anggaran biaya siswa. Seperti yang dapat kita lihat pada gambar di bawah ini :.

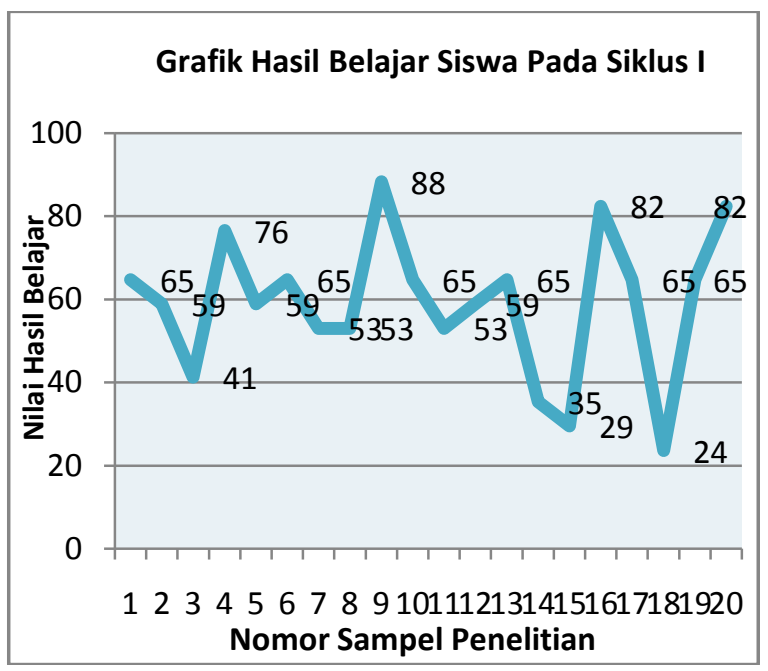

Gambar 4. Grafik Hasil Belajar Siklus II
Adapun keberhasilan yang diperoleh selama siklus kedua ini adalah sebagai berikut :

1) Aktivitas belajar siswa dalam proses belajar mengajar sudah mengarah kepembelajaran kolaboratif. Siswa mampu untuk saling berbagi dalam memecahkan masalah yang ada dalam kelompok sendiri maupun pada kelompok lainnya.

2) Hasil belajar siswa juga meningkat pada siklus II yaitu dengan rata-rata 69,81 pada siklus I meningkat menjadi 84,71 pada siklus II.

Hal ini membuktikan bahwa siklus selanjutnya tidak perlu dilakukan lagi. Oleh karena itu Penerapan pembelajaran kolaboratif dapat meningkatkan Aktivitas dan hasil belajar kelas XI Kompetensi Keahlian Teknik Gambar Bangunan pada kompetensi rencana anggaran biayadi SMK N 2 siatas Barita.

Dari hasil belajar pada siklus I dan siklus II dapat disimpulkan bahwa terjadi perbaikan pada setiap indikator, terutama pada Aktivitas dan hasil belajar siswa, sehingga penerapan Pembelajaran kolaboratif dapat meningkatkan aktivitas dan hasil belajar siswa pada mata pelajaran menerapkan dasar -dasar gambar teknik. Berikut grafik peningkatan aktivitas dan hasil belajar pada siklus I dan siklus II :

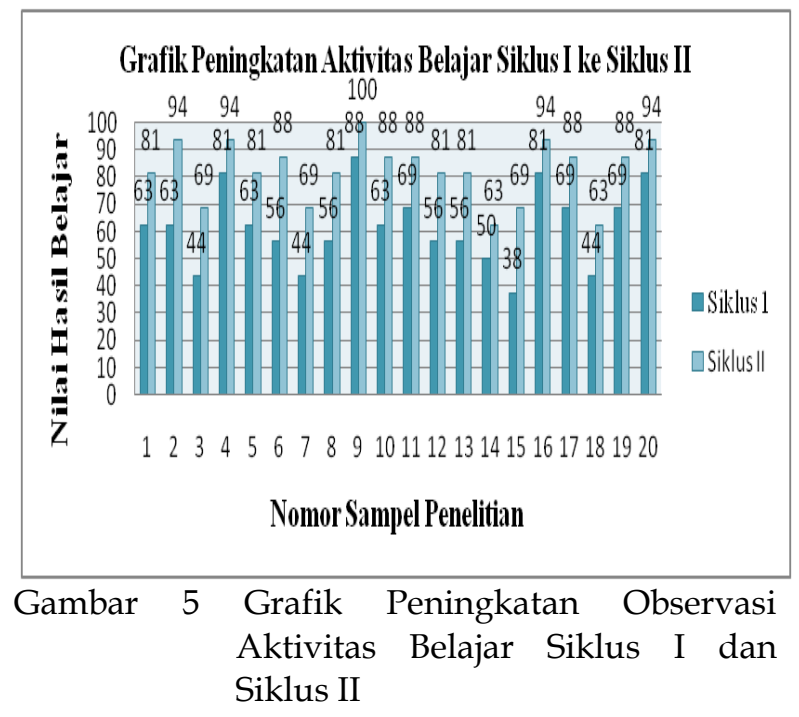




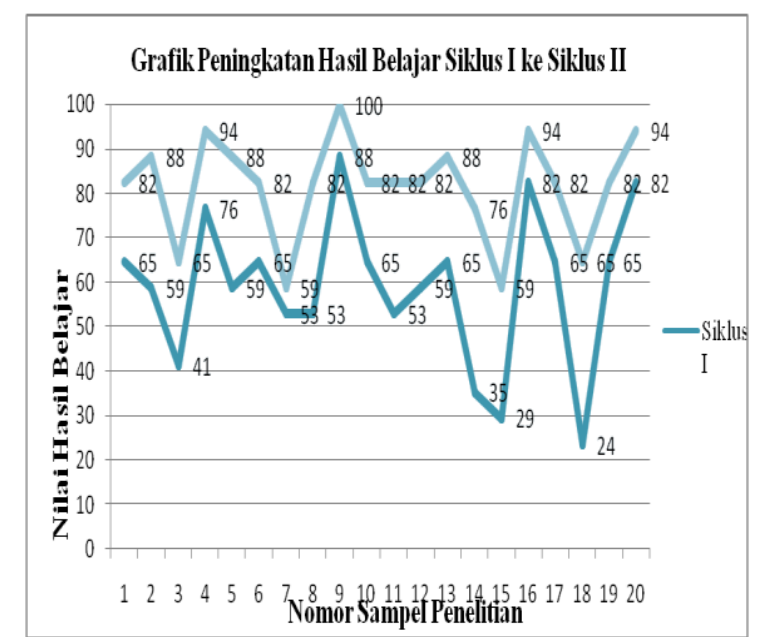

Gambar 6 Grafik Peningkatan Hasil Belajar Siklus I dan Siklus II

\subsection{Uji Hipotesis Penelitian}

Untuk menguji hipotesis dalam penelitian ini, digunakan teknik analisa statistik deskriptif yaitu mencari nilai rata-rata dan presentase keberhasilan belajar.

1) Dengan menerapkan pembelajaran model kolaboratif dapat meningkatkan aktivitas belajar siswa kelas XI kompetensi keahlian teknik gambar bangunan SMK N 2 Siatas Barita. Hipotesis pertama menyatakan dapat meningkatkan Aktivitas belajar siswa pada siklus I diketahui siswa yang memperoleh nilai dengan kategori Tidak aktif tidak ada, Kurang aktif 7 orang $(23,33 \%)$, Cukup aktif 8 orang $(26,67 \%)$,Aktif 12 orang $(40,00 \%)$ dan Sangat aktif 3 orang (10,00\%). Dari nilai ideal 16 , nilai perolehan rata-rata hanya 7,83 dan persentase klasikal 50,00 yaitu dalam kategori cukup aktif sehingga perlu dilakukan peningkatan pada siklus II. Setelah dilakukan pengamatan pada siklus II maka terjadi peningkatan terhadap Aktivitas belajar siswa yaitu dengan Aktivitas belajar siswa dengan kategori Tidak aktif tidak ada, Kurang aktif tidak ada, Cukup aktif 3 orang $(10,00 \%)$, Aktif 20 orang $(66,67 \%)$ dan Sangat Aktif 7 orang $(23,33 \%)$. Dari nilai ideal 16, nilai perolehan rata-rata hanya 10,9 dan persentase klasikalnya 90,00 yaitu tergolong dalam kategori aktif. Maka dapat disimpulkan dengan menerapkan Pembelajaran Model Kolaboratif dapat meningkatkan Aktifitas belajar siswa dalam mata pelajaran menerapkan dasar-dasar gambar teknik pada sub materi Mendeskipsikan peralatan gambar pada siswa kelas XI kompetensi keahlian teknik gambar bangunan SMK N 2 Siatas Barita.

2) Dengan menerapkan pembelajaran model kolaboratif dapat meningkatkan hasil belajar siswa kelas XI kompetensi keahlian teknik gambar bangunan SMK N 2 siatas Barita. Pada pre tes sebelum menggunakan model tipe kolaboratif terdapat 3 siswa $(10,00 \%)$ dikatakan kompeten, 10 siswa $(40,00 \%)$ dikatakan cukup kompoten, 15 siswa ( 50,00\% ) dikatakan tidak kompoten, dengan rata-rata 66,30 , dengan persentase klasikal 10,00 yaitu kategori tidak kompoten (Belum Tuntas). Kemudian dilakukan pembelajaran kembali pada siklus I dengan menggunakan model kolaboratif, diketahui siswa yang memperoleh nilai dengan kategori tidak kompeten 11 orang $(36,67 \%)$, cukup kompeten 14 orang $(46,67 \%)$, dan kompeten 4 orang $(13,33 \%)$, dan sangat kompeten 1 orang (3,33\%). Dari nilai ideal 100, nilai perolehan rata-rata hanya 69,81 dengan persentase klasikal 16,67 yaitu masih dikatakan kategori Tidak Kompeten ( belum tuntas ), sehingga perlu dilakukan perbaikan pada siklus II. Setelah dilakukan pengamatan pada siklus II maka terjadi peningkatan terhadap hasil belajar siswa yaitu dengan hasil belajar siswa dengan kategori tidak kompeten tidak ada, ,cukup kompeten 8 orang $(26,67 \%)$, kompeten 15 orang $(50,00 \%)$, dan sangat kompeten 7 orang $(23,33 \%)$. Dari nilai ideal 100 , nilai perolehan rata-rata hanya 84,71 dengan persentase klasikal 73,33 tergolong dalam kategoti kompeten. Maka dapat disimpulkan dengan menerapkan pembelajaran model kolaboratif dapat meningkatkan hasil belajar RAB siswa kelas XI kompetensi keahlian teknik gambar bangunan SMKN 2 Siatas Barita.

\section{Kesimpulan dan Saran}

\subsection{Kesimpulan}

Dari hasil analisis data dan pembahasan maka dapat diambil kesimpulan, yaitu aktivitas belajar siswa selama penerapan model pembelajaran kolaboratif pada siklus I kurang mencapai standar minimal yang diharapkan, sehingga perlu dilakukan siklus lanjutan (siklus II). Hasil belajar siswa setelah dilakukan penerapan model pembelajaran kolaboratif adalah mengalami 


\section{Penerapan Model Pembelajaran Kolaboratif Untuk Meningkatkan Aktivitas dan hasil Belajar Rencana Anggaran Biaya Siswa Kelas XII Kompetensi keahlian Teknik Gambar Bangunan SMKN 2 Siatas Barita - Tapanuli Utara}

peningkatan, yaitu dari siklus I dengan rata-rata 55 meningkat menjadi 81 pada siklus II dengan mengalami peningkatan sebesar $22 \%$. Dari hasil peningkatan hasil belajar tersebut berarti penerapan model pembelajaran kolaboratif pada materi pekerjaan struktur dan non struktur serta perhitungan pekerjaan struktur dan non struktur mengalami peningkatan. Oleh karena itu, penerapan model pembelajaran kolaboratif dapat meningkatkan aktivitas dan hasil belajar RAB Kompetensi Keahlian Teknik Gambar Bangunan SMKN 2 Siatas Barita.

\subsection{Implikasi}

Hasil kesimpulan menyatakan siswa yang diajar menggunakan model pembelajaran kolaboratif memperoleh hasil belajar RAB lebih tinggi jika dibandingkan dengan siswa yang diajar dengan metode pembelajaran Konvensional. Dengan diterimanya hipotesis dalam penelitian ini, maka model pembelajaran kolaboratif ini dapat dijadikan sebagai pilihan metode pembelajaran bagi guru khususnya guru standar kompetensi RAB dalam melaksanakan proses pembelajaran.

Penggunaan model pembelajaran yang tepat akan menciptakan suasana belajar yang lebih baik demi tercapainya hasil belajar yang baik pula. Penerapan model pembelajaran kolaboratif menjadi salah satu bukti bahwa pembelajaran juga menuntut aktivitas siswa dan guru untuk mengembangkan potensi yang ada di dalam diri siswa.

\subsection{Saran}

Berdasarkan kesimpulan di atas maka disarankan beberapa hal sebagai berikut :

1) Sebaiknya guru memberikan motivasi dan dorongan kepada siswa setiap kali sebelum pembelajaran dimulai.

2) Situasi ruang belajar harus menarik dan menantang dalam proses belajar mengajar.

3) Guru harus melatih keterampilan dan mendorong keberanian siswa dalam menjawab dan mengajukan pertanyaan.

4) Bagi guru khususnya guru standar kompetensi RAB sebaiknya menggunakan model pembelajaran kolaboratif sebagai salah satu alternative dalam mata pembelajaran RAB untuk meningkatkan aktivitas dan hasil belajar siswa.
5) Siswa harus lebih serius dalam mendalami materi pembelajaran dan lebih sering melakukan kerja kelompok dalam membahas materi.

6) Siswa lebih aktif dalam belajar dengang menggunakan model kolaboratif.

7) Pihak sekolah harus menambah referensi materi yang akan diajarkan sehingga perhatian siswa lebih terfokus pada materi pelajaran dalam meningkatkan hasil belajar siswa.

8) Untuk penelitian lebih lanjut.

\section{Daftar Pustaka}

Arikunto, S. 2003. Manajemen Penelitian. Jakarta: Rineka Cipta

Arikunto, S. 2006. Dasar-Dasar Evaluasi Pendidikan. Jakarta: Bumi Aksara

Arikunto, dkk. 2008. Penelitian Tindakan Kelas. Jakarta : Bumi Aksara.

Djamarah, dkk. 2008. Strategi Belajar Mengajar. Jakarta : Rineka Cipta.

Daryanto, 2010. Evaluasi Hasil Belajar. Jakarta: Rineka Cipta.

Hamalik, O. 2009. Proses Belajar Mengajar. Jakarta : Bumi Aksara

Istarani. 2011. 58 Model Pembelajaran Inovatif. Medan : Media Persada

Jakob Et Al. 1996. Belajar Tentang kehidupan Nyata. Http:// Tulisansingkatemail. blogspot.com/?view=sidebar. Diakses Tangggal 27 April 2014

John M. 1991. Metode Pembelajaran Kolaboratif. Http:// Tulisansingkatemail. blogspot.com/?view=sidebar. Diakses Tangggal 27 April 2014

Johnsons. 1974. Unsur Dasar Pembelajaran Kolaboratif. Http:// Tulisansingkatemail. blogspot.com/?view=sidebar. Diakses Tangggal 27 April 2014

Kunandar. 2008. Langkah Mudah Penelitian Tindakan Kelas Sebagai Pengembangan Profesi Guru. Jakarta : Rajawali Pers

Mudyaharjo. 2001. Hakikat Pendidikan. Http:// Belajarjadiguruprofesional.

blogspot.com/?view=sidebar. Diakses Tangggal 27 April 2014 
Mukomoko. 2011. Dasar Penyusunan Anggaran Biaya Bangunan. Jakarta : Yofa Mulia Offset

Nurasman. 2006. Model Pembelajaran Kolaboratif. Error! Hyperlink reference not valid.. Diakses tanggal 29 oktober 2013

Reid. 2004. Tahapan Mengembangkan Pembelajaran Kolaboratif. Http:// Tulisansingkatemail. blogspot.com/?view=sidebar. Diakses Tangggal 27 April 2014

Rohani, A. 2004. Pengelolaan Pengajaran. Jakarta: Rineka Cipta.

Sanjaya. 2006. Strategi Pembelajaran. Jakarta : Kencana.

Sardiman. 2009. Interaksi dan Motivasi Belajar Mengajar. Jakarta : Raja Grafindo Persada.

Slameto. 2003. Belajar dan Fakto-faktor Yang Mempengaruhinya. Jakarta : Rineka Cipta

Smith \& MG. 1992. Metode Kolaboratif Didasarkan Pada Asumsi-Asumsi Mengenai Proses Belajar Siswa. Http:// Tulisansingkatemail. blogspot.com/?view=sidebar. Diakses Tangggal 27 April 2014

Sudjana, N. 2009. Penilaian Hasil Proses Belajar Mengajar. Bandung : Remaja Rosdakarya

Sugiono. 2009 ; 96. Rancangan Penelitian. Jakarta : Rineka Cipta

Ted Panitz. 1996. Pengertian Kolaboratif. Http:// Tulisansingkatemail.

blogspot.com/?view=sidebar. Diakses Tangggal 27 April 2014

Trianto. 2007. Model- Model Pembelajaran Inovatif Berorientasi Konstruktivistik. Jakarta: Prestasi Pustaka.

Yasa. 2008. Prestasi Belajar. http://ipoteswordpress.com/2009/05/24.

Diakses tanggal 29 september 2013. 